\title{
JOBCHANCE DEUTSCH - UČEBNICE NĚMECKÉ FIREMNÍ KOMUNIKACE PRO STŘEDNĚ POKROČILÉ
}

\author{
Věra Höppnerová \\ Vysoká škola ekonomická v Praze, Fakulta mezinárodních vztahů, Katedra němčiny, \\ U Zeleného ptáka 1158, 14800 Praha 4, Česká republika \\ e-mail: hopp@vse.cz
}

\begin{abstract}
Abstrakt
V článku jsou shrnuty výsledky dosavadních výzkumů vzdělávacích potřeb studentů němčiny na vysokých školách ekonomického zaměření v České republice. Z těchto výzkumů vychází nová učebnice německé firemní komunikace „Jobchance Deutsch“, určená studujícím stř̌edně pokročilé úrovně B1. Její texty vybízejí k zaujetí stanoviska ke kontroverzním tématům a mluvnické jevy jsou vybrány sohledem na jejich frekvenci vodborné komunikaci. Nejobsáhlejší oddíl učebnice - partie cvičení - obsahuje cvičení určená pro párovou práci, cvičení na kolokace, cvičení lexikální a fonetická, cvičení na rozvíjení písemného vyjadřování a řadu dalších.
\end{abstract}

\section{Keywords}

Communication skills; Current demands of labour market; Business communication; German textbook.

\section{Úvod}

Výzkum komunikativních dovedností studujících - v našem př́ípadě studentů ekonomie patří k evergreenům didaktiky. Není divu: potřeby praxe se mění a rovněž tak i výchozí znalosti studujících. Jaké schopnosti a dovednosti by měli mít současní absolventi Vysoké školy ekonomické? Máme se soustředit na četbu odborných textů jako zdroje informací? Nebo současně rozvíjet i obecný jazyk na vyšší úrovni? Nebo se spíše zaměřit na odbornou komunikaci? Jakou roli má hrát ve výuce písemné vyjadřování?

Chceme-li odpovědět na tyto otázky, nemůžeme vycházet $\mathrm{z}$ tradičních názorů nebo ze subjektivních úvah či zkušeností. Teprve znalost skutečných potřeb dané cílové skupiny nám pomůže určit obsah učebních plánů, kurzů, učebnic a metodické postupy.

Výzkumy vzdělávacích potřeb absolventů vysokých škol ekonomického zaměření byly prováděny $\mathrm{v}$ minulosti již několikrát a $\mathrm{v}$ budoucnu se $\mathrm{v}$ nich bude jistě pokračovat, nebot' nás praxe staví před stále nové úkoly a jazyková úroveň absolventi̊ středních škol se v př́padě němčiny nelepší - $\mathrm{v}$ př́ípadě němčiny spíše naopak.

\section{Dosavadní výzkumy vzdělávacích potř̌b studentů hospodářského jazyka}

První výzkum vzdělávacích potřeb studentů ekonomie byl proveden na Vysoké škole ekonomické v létech 1992-1993 (Höpppnerová [3]). Z 250 dotázaných absolventi̊ odpovědělo 62 respondentů, kteří kladli na první místo dovednost odborné ústní komunikace, dále obecné ústní komunikace, telefonování a psaní obchodní korespondence před četbou odborných textů. Co se týče poměru odborné a obecné komunikace klonily se váhy zřetelně ve prospěch komunikace odborné - u téměř poloviny respondentů velmi výrazně. $Z$ výzkumu 
vyplynula mj. prvořadá důležitost odborné ústní komunikace, telefonického styku a obchodní korespondence a až v druhé řadě dovednost četby odborných textů.

Zatímco byly $\mathrm{v}$ tomto výzkumu zjišt'ovány potřeby studentů, obrátil se Potocký [6] na vyučující učitele němčiny na vysokých školách (20), na zaměstnance (30) a zejména na studenty (350). Nejvíce potíží působila podle jeho zjištění studentům v odborné komunikaci neznalost odborného lexika a mluvnice. Z písemné komunikace přikládali - což se dalo očekávat - větší význam psaní e-mailů než psaní abstrakt vědecké práce. Všechny skupiny dotazovaných považovaly za nezbytné nácvik zdvořilostních obratů a text seznamující s reáliemi a kulturními hodnotami dané země, což svědčí o zájmu studujících o studium v zahraničí.

Třetí výzkum provedla Jeřábková v r. 2015 na Vysoké škole ekonomické mezi 133 absolventy. Z nich první skupina (55) absolvovala kurzy němčiny jako 1. cizí jazyk a druhá (43) jako 2. cizí jazyk s nižší hodinovou dotací. Všichni končili své studium v létech 20082010.

Naprostá většina respondentů první skupiny se ve své profesní praxi zabývala četbou různých materiálů a podkladů, psaním e-mailů, vyhledáváním informací na internetu, telefonováním, komunikovala na služebních cestách či při jednáních s obchodními partnery a kolegy v práci, překládala do češtiny a do němčiny. Práce s odborným textem v jeho nejrůznějších podobách tak svědčí o významu receptivní dovednosti. $Z$ výzkumu dále vyplývá důležitost komunikace pomocí médií. Téměř všichni komunikovali pomocí e-mailů a velká část telefonovala, což klade značné nároky na porozumění. Nezanedbatelnou není ani potřeba oboustranného překladu, kterému současná kurikula nevěnují žádnou pozornost. Požadavek jednojazyčné výuky je tudíž didakticky překonaný (Jeřábková [4, s. 113]).

Respondenti si cenili ve výuce nejvíce vyučujících a výuky odborného jazyka, kterou nemohou jinde získat. Na dotaz, zda se cítili jazykově připraveni na profesní praxi, jich odpovědělo $70 \%$,spíše ano“.

Hodnocení druhé skupiny studentů, kteří měli němčinu na VŠE jako druhý jazyk, je naproti tomu negativní. Pro využití němčiny v profesní praxi se jich naprostá většina necítila připravena a $\mathrm{v}$ praxi ji využívala málo, nebot' se na VŠE ve čtyřsemestrálním kurzu s odborným jazykem nesetkala. Pokud byli nuceni překládat, činilo jim tom značné potíže. Ve výuce používaná učebnice obecného jazyka na bázi němčiny (Schritte international, Hueber Verlag 2021) je na tuto činnost nemohla připravit.

Poslední, 4. výzkum, provedly Jeřábková a Höppnerová [5]. Jejich respondenty (40) byli studující VŠE, kteří vedle studia pracují u různých německých, rakouských či švýcarských firem. Podrobná hodinová interview s každým respondentem ukázala potřebnost všech řečových dovedností (čtení, poslechu, mluvení i psaní), jejichž podíl závisí na charakteru vykonávané práce. Podobně jako předchozí výzkumy ukázal i tento potřebnost dovednosti překladu. Nejméně potíží činilo respondentům čtení s porozuměním a poslech - pokud ovšem partner nemluvil prŕlišs rychle nebo dialektem, a psaní e-mailů.

Za nejobtížnější považují respondenti ústní komunikaci, v menší míře odbornou a ve větší míře obecnou. Střední škola je na ni připravila nedostatečně a na vysoké škole se při nízké hodinové dotaci upřednostňuje komunikace odborná. Ústní komunikaci stěžují nedostatky v gramatice a omezená slovní zásoba. Opětně se objevují stížnosti na nedostatečný rozsah jazykové výuky, příliš velký počet posluchačů ve výuce a chybějící výuku v magisterském studiu. Co do obsahu výuky je požadován větší podíl konverzace včetně konverzace v obecném jazyce a dále opakování a rozšiřování gramatiky, ve které pocit’uji nedostatky 
a mezery. Z vyučovacích metod si respondenti nejvíce cení párové či skupinové práce, zařazování aktualit do výuky a prezentací.

Rozsáhlé pohovory s respondenty přinesly řadu nových poznatků, týkajících se obsahu výuky i metodického postupu, a vytvořily př́źznivé předpoklady pro tvorbu nového učebního materiálu firemní komunikace.

\section{Učebnice, „Jobchance Deutsch““}

Učebnice „Jobchance Deutsch“ byla motivována kritickým postojem studentů k zmíněné jednojazyčné učebnici obecného jazyka, která studující nepřipravuje na profesní praxi. Učebnice je určena středně pokročilým studentům bakalářského studia úrovně B1, kteří mají základní znalosti obecné němčiny. Bez znalostí základů firemní komunikace se ovšem na trhu práce uplatnit nemohou. Na základě zajímavých a obsahově pestrých textů jsou rozvíjeny odborné jazykové znalosti. Pomocí širokého souboru komunikativních cvičení jsou zopakovány a doplněny základy mluvnice.

\section{$2.1 \quad$ Texty}

Texty jsou východiskem a základem každé lekce. Jejich témata uživatele zaujmou a rozšsiří jejich znalosti. Značná část textů této učebnice splňuje však ještě jeden cíl - vede k zaujetí vlastního stanoviska k danému problému. Jsou to tedy vesměs témata kontroverzní: Jaké jsou výhody a nevýhody samostatného podnikáni? Je lepši pracovat v menši či velké firmě? Znamená cestovní ruch jen ekonomický prínos nebo má i dopad na životní prostředí? Jaké jsou klady a zápory práce vedle studia? Proč se bez reklamy neobejdeme, když nám často znepř́jemňuje život? Jaké jsou kladné a záporné stránky práce online? atd.

Protože řada studujících vedle studia pracuje, může srovnávat zde prezentované skutečnosti s vlastní zkušeností, at' již jde o organizační strukturu podniku, firemní kulturu nebo dress code. Stejně tak je možné porovnávat prezentované informace s vlastním studiem v zahraničí, pracovním pobytem v Německu nebo dobrovolnickou prací v zahraničí.

V souladu s provedenými výzkumy jsou věnovány celé dvě lekce telefonování, které je dnes neodmyslitelnou součástí firemní komunikace.

Jednotlivé lekce obsahují rovněž ukázky písemné firemní komunikace, pozvánku na přijímací pohovor, žádost o praxi, pozvánku a program podnikové schůze, pozvánku na vánoční podnikovou oslavu, záznamy telefonických rozhovorů aj.

Jednotlivé lekce jsou lexikálně vyvážené - obsahují kolem 40 slov a slovních spojení a nejsou tak ani lexikálně přetížené.

Každá lekce má jeden výchozí a jeden kratší doplňkový text na závěr lekce, který rozvíjí dané téma, popř. ukázku písemné komunikace. I doplňkový text je didakticky zpracován obsahuje cvičení a vysvětlení neznámé slovní zásoby.

\subsection{Gramatika}

Mluvnický výklad a procvičování mluvnických jevů tvoří zvláštní oddíl učebnice „Grammatiktraining“. Důvodem oddělení mluvnického výkladu a mluvnických cvičení je, že by jejich zařazení do tematicky vyhraněných lekcí působilo rušivě. Jednotlivé mluvnické jevy jsou procvičovány jak v oddíle „Grammatiktraining“, tak i v jednotlivých lekcích učebnice ve spojení s novou slovní zásobou.

Učebnice obsahuje celkem 67 jevů, takže při 29 lekcích připadají na každou lekci 2 až 3 mluvnické jevy. Jednotlivé lekce jsou tak mluvnicky spíše „odlehčené““. 
Závěr mluvnice, kam bývají obvykle zařazovány nejtěžší mluvnické jevy, tvoří konjunktiv würde + infinitiv a konjunktiv préterita pouze u modálních a způsobových sloves. Výklad mluvnice začíná od nuly. Neobvyklé je proto zařazení vedlejších vět již do 5 . lekce. Jak ukazuje výzkum chyb v písemných projevech středoškoláků (Burgerová [1]), ovládají středoškolští studenti syntaktické jevy pouze z $37 \%$ (znalost morfologických jevů je podstatně lepší).

Výklad mluvnice je jasný, stručný a nekomplikovaný. Všechny př́kladové věty jsou při výkladu mluvnice přeloženy do češtiny. Jelikož jde o učebnici hospodářského a ne obecného jazyka, jsou př́iklady vzaty převážně z jazyka hospodářského a ne obecného, jak tomu je u učebnic obecného jazyka.

\subsection{Cvičení}

Cvičení tvoří největší část učebnice - 3/4 jednotlivých lekcí i oddílu „Grammatiktraining““ V souladu s poznatky posledního výzkumu jsou pevnou součástí každé lekce cvičení určená pro párovou práci typu „Pracujte ve dvojicích“, která umožňují zapojit do práce všechny studenty najednou. V některých lekcích je takovýchto cvičení několik. Aktivita všech studujících najednou vyváží fakt, že se při párové práci dopouštějí chyb.

Každá lekce obsahuje rovněž cvičení na kolokace typu „Co k sobě patří?“ Slouží upevňování častých slovních spojení (nebenbei jobben, eine Ausschreibung gewinnen, Überstunden machen). Vycházíme z poznatku „Wortschatzlernen ist Kollokationslernen“ (Hausmann 1984 [2]), tj. že nestačí umět slovíčka, ale je třeba vědět, v jakém spojení či kontextu je užít.

$\mathrm{V}$ učebnicích odborného jazyka vesměs chybí cvičení na rozvíjení písemného projevu. Pokud jsou ale témata lekcí spjata s profesním životem nebo s vlastními poznatky a zkušenostmi, není těžké takové náměty najít. V každé lekci jsou proto obsaženy úkoly napsat pojednání typu „Představte firmu vašich rodičů či přátel“, „Vyličte firemní kulturu vašeho pracoviště““, „Napište o svém postoji k životnímu prostředí“, „Charakterizujte váš vztah k reklamě“ atd.

Zkušenosti s učebnicí ukazují, že studující rádi formulují své myšlenky, názory a poznatky, a přitom využívají slovní zásobu, kterou si v dané lekci osvojili.

Vedle nejrůznějších typů cvičení gramatických, lexikálních a konverzačních je třeba zmínit i cvičení na dovednost, nad kterou jsme ve výuce odborného jazyka vesměs zlomili hůl, a to výslovnost. Nedělám si iluze, že se zařazením fonetických cvičení výslovnost studujících rapidně zlepší, ale za pokus to stojí. Není marné upozornit na zaokrouhlené $\ddot{o}$ a $\ddot{u}$, zavřené dlouhé $e$ a $o$, aspirovaná $\mathrm{p}, \mathrm{t}, \mathrm{k}$, redukci $e \mathrm{v}$ nepř́ízvučných slabikách -el, -er, -en, silnější př́zvuk v němčině, často odlišný u cizích slov. Součástí oddílu věnovaného procvičování dále patři partie, kterou bychom mohli nazvat „Opakování matka moudrosti“. Jde o opakovací testy, zařazené za každou třetí lekcí, takže je v učebnici celkem 9 opakovacích testů. Každý z nich osahuje zhruba 6 cvičení. Testují se probrané mluvnické jevy, slovní zásoba a především schopnost formulovat odpovědi na otázky týkající se témat probraných tří lekcí. Jednotlivá cvičení jsou obodována a následně uvedeno bodové rozpětí odpovídající známkám 1, 2 a 3. Tím je studujícím umožněna sebekontrola a vlastní ohodnocení znalostí.

\section{$3 \quad$ Práce s učebnicí, metodika, vzdělávací cíl}

Podle učebnice jsem pracovala dva semestry, oba online, pokaždé se studenty odlišné úrovně. Protože byla prozatím akreditována jako volně volitelný jednosemestrálním kurz, nemohla jsem probrat všech 29 lekcí, ale pouze 10. Těžišstě výuky spočívalo v první (textové) části učebnice, mluvnici a cvičení oddílu „Grammatiktranining“ jsem probírala, pokud jsem 
u studujících zjistila slabiny. U obou kurzů mě překvapila aktivita a chut' diskutovat, což bylo také hlavním cílem kurzu. Kurz si studující zvolili, protože se chtěli „rozmluvit“. A to se jim také vesměs podařilo. Mluvnická stránka jejich projevu byla slabší, protože některé chyby již měli dlouhým užíváním zafixované.

Co se týče metodiky, vyplývá z uvedeného, že učebnice rozvíjí základní komunikativní dovednosti - dovednost mluvení, čtení a psaní. Nahrávky, sledující nácvik poslechu $\mathrm{s}$ porozuměním, budou pořízeny současně s jejím vydáním.

Cílem učebnice však není jen komunikace za každou cenu bez ohledu na slovosled, koncovky nebo volbu správného výrazu. Na absolventy vysoké školy bychom měli klást vyšší požadavky. Proto učebnice upozorňuje na mluvnické a lexikální rozdíly s mateřštinou a obsahuje dostatek cvičení, která pomohou středoškolské deficity odstranit. Záleží jen na vyučujícím, kolik času bude ochoten jim věnovat.

Učebnici včetně ilustrací k textové i mluvnické části dostali v elektronické podobě, protože se nakladatelství tvrdě postižená pandemií do nových projektů nechtěla pouštět. To se ovšem může změnit, pokud se podaří zjistit, které školy, firmy aj. pracoviště by o ni měly zájem. Jak již naznačuje název „Jobchance Deutsch“, představuje znalost německé firemní komunikace konkurenční výhodu na trhu práce a ovlivňuje významným způsobem budoucí kariéru absolventů.

\section{Závěr}

Výzkum uplatnění jazykových dovedností absolventů Vysoké školy ekonomické v praxi ukázal, že naprostá většina absolventů němčiny jako 2. cizího jazyka na požadavky praxe připravená není. To vedlo k vypracování učebnice firemní komunikace „Jobchance Deutsch“ (úroveň B1), zohledňující předchozí výzkumy jazykových potřeb v profesní praxi. Její předností jsou zajímavá kontroverzním témata, vybízející k formulování vlastního stanoviska, nácvik mluvnických jevů, typických pro hospodářský jazyk a bohatý výběr cvičení na rozvíjení ústního i písemného projevu.

\section{Literatura}

[1] BURGEROVÁ, E.: Analýza syntaktických chyb v písemných projevech středoškoláků. Fakulta pedagogická Západočeské univerzity v Plzni, katedra němčiny, Plzeň, 2020.

[2] Franz Josef Hausmann. In: Wikipedia. [encyclopedia online]. Wikimedia Foundation Inc. Diese Seite wurde zuletzt am 27. Oktober 2021 um 15:23 Uhr bearbeitet. Available from WWW: https://de.wikipedia.org/wiki/Franz_Josef_Hausmann

[3] HÖPPNEROVÁ, V.: Požadavky hospodářské praxe na jazykové dovednosti. Cizi jazyky. 1996/97, ročník 40, č. 5-6, s. 86-88.

[4] JEŘÁBKOVÁ, P.: Kurikulum odborné němčiny na vysoké škole odborného zaměření teorie a praxe. Disertační práce, Vysoká škola ekonomická v Praze, Fakulta financí a účetnictví, Katedra didaktiky ekonomických předmětů, Praha, 2016.

[5] JEŘÁBKOVÁ, P.; HÖPPNEROVÁ, V.: Inovace výuky hospodářské němčiny na základě potřeb hospodářské praxe. Interní grant VŠE pro rok 2019, Vysoká škola ekonomická v Praze.

[6] POTOCKÝ, T.: Vzdělávací standard pro profesně zaměřenou výuku německého jazyka na vysokých školách s ekonomickou profilací. Disertační práce, 2013. Available from WWW: https://dspace.cuni.cz/handle/20.500.11956/52944?show=full

prof. PhDr. Věra Höppnerová, DrSc. 


\section{JOBCHANCE DEUTSCH - TEXTBOOK OF GERMAN CORPORATE COMMUNICATION FOR INTERMEDIATE STUDENTS}

The article summarizes the results of previous research on educational needs of German students at universities of economics in the Czech Republic. The new textbook of German corporate communication entitled "Jobchance Deutsch", intended for intermediate B1 students, is based on this research. The texts it contains encourage studets to express their opinion concerning controversial topics. Grammatical phenomena are selected with regard to their frequency in professional communication. The most comprehensive section of the textbook - the exercises section-contains exercises designed for pairwork, collocation ones or lexical and phonetic ones as well as those meant to make develop students' written expression and many others.

\section{JOBCHANCE DEUTSCH - LEHRBUCH FÜR FIRMENKOMMUNIKATION FÜR MÄSSIG FORTGESCHRITTENE}

In diesem Beitrag werden die Ergebnisse der bisherigen Untersuchungen zu den Bildungsbedürfnissen der Studenten in Sachen Deutsch an den Hochschulen mit ökonomischer Ausrichtung in der Tschechischen Republik zusammengefasst. Aus diesen Untersuchungen geht ein neues Lehrbuch für deutsche Firmenkommunikation hervor: „Jobchance Deutsch“, welches mäßig fortgeschrittenen Studierenden auf dem Niveau B1 zugutekommen soll. Die darin enthaltenen Texte fordert dazu auf, zu kontroversen Themen Stellung zu beziehen, und grammatische Erscheinungen sind mit Rücksicht auf deren Frequenz in der fachlichen Konversation ausgesucht. Der umfangreichste Teil dieses Lehrbuchs, der Übungsteil, enthält Übungen, welche für Paararbeit gedacht sind, Kollokationsübungen, lexikalische und phonetische Übungen, Übungen zur Entfaltung der schriftlichen Ausdrucksfähigkeit u. a.

\section{JOBCHANCE DEUTSCH - PODRĘCZNIK NIEMIECKIEJ KOMUNIKACJI W FIRMIE DLA ŚREDNIO ZAAWANSOWANYCH}

$\mathrm{W}$ artykule podsumowano wyniki dotychczasowych badań dotyczących potrzeb edukacyjnych studentów języka niemieckiego na uczelniach wyższych o kierunkach ekonomicznych w Republice Czeskiej. Na bazie przeprowadzonych badań oparto nowy podręcznik niemieckiej komunikacji w firmie „Jobchance Deutsch”, przeznaczony dla studentów średnio zaawansowanych na poziomie B1. Jego treść zachęca do ustosunkowania się do kontrowersyjnych tematów a zjawiska gramatyczne dobrano przy uwzględnieniu ich częstotliwości występowania w komunikacji specjalistycznej. Najobszerniejsza część podręcznika - ćwiczenia - zawiera ćwiczenia przeznaczone do pracy w parach, ćwiczenia na kolokację, ćwiczenia leksykalne i fonetyczne, ćwiczenia rozwijające wypowiedź pisemną i wiele innych. 